CASSOWARY - Volume 1 (2):81 - 88

ISSN : 2614-8900

E-ISSN : 2622-6545

CProgram Pascasarjana Universitas Papua, https://pasca.unipa.ac.id/

\title{
Estimasi nilai heritabilitas, ripitabilitas, korelasi genetik produksi susu dan kadar lemak Sapi Perah Fries Holland pada laktasi pertama dan kedua di Balai Besar Pembibitan Ternak Unggul - Hijauan Pakan Ternak Baturraden
}

Estimation of heritability, repeatability and genetic correlation of milk production and fat content of Fries Holland milk cattle at first and second lactation in Balai Besar Pembibitan Ternak Unggul - Hijauan Pakan Ternak Baturraden

\author{
Nani S Kubangun ${ }^{1)}$, Since Lumatauw ${ }^{2)}$ dan Budi Santoso ${ }^{2 *}$ \\ ${ }^{1)}$ Program Studi S2 Ilmu Peternakan Universitas Papua \\ ${ }^{2)}$ Fakultas Peternakan Universitas Papua \\ Jalan Gunung Salju Amban, Manokwari, Kodepos 98314, Papua Barat Indonesia
}

*Email: b.santoso@unipa.ac.id

\begin{abstract}
This study aims to determine the value of heritability, ripitability, genetic correlation and fat level of dairy cows in the first and second lactation. The results showed that the heritability value obtained was categorized high. The heritability value of daily milk production in the first lactation was $0.402 \pm 0.259$ and in the second lactation was $0.54 \pm 0.301$. Heritability value of fat content obtained is high that is $0.63 \pm 0.39$. The average value of milk production ripitability and the value of ripitability of fat level including high value category that is equal to $0.49 \pm 0.325$ and $0.93 \pm 0.13$. The genetic correlation value of milk production and fat level obtained in this study was $2.91 \pm 0.83$.
\end{abstract}

Keywords: heritability, repeatability, genetic correlation, milk production, fat Level

ABSTRAK: Penelitian ini bertujuan untuk mengetahui nilai heritabilitas, ripitabilitas, korelasi genetik dan kadar lemak sapi perah pada laktasi pertama dan laktasi kedua. Hasil penelitian menunjukkan bahwa nilai heritabilitas yang diperoleh dikategorikan tinggi. Nilai heritabilitas produksi susu harian pada laktasi pertama 0,402 $\pm 0,259$ dan pada laktasi kedua adalah $0,54 \pm 0,301$. Nilai heritabilitas kadar lemak yang diperoleh adalah tinggi yakni $0,63 \pm 0,39$. Rataan nilai ripitabilitas produksi susu dan nilai ripitabilitas kadar lemak termasuk kategori nilai tinggi yakni sebesar $0,49 \pm 0,325$ dan $0,93 \pm 0,13$. Nilai korelasi genetik produksi susu dan kadar lemak yang diperoleh dalam penelitian ini adalah sebesar $2,91 \pm 0,83$.

Kata Kunci: heritabilitas, ripitabilitas, korelasi genetik, produksi susu, kadar lemak

\section{PENDAHULUAN}

\section{Latar Belakang}

Sapi Fries Holland merupakan bangsa sapi perah yang dipelihara oleh peternak di Indonesia dengan tujuan mendapatkan produksi susunya. Bangsa sapi Fries Holland berasal dari Eropa, yaitu Belanda (Nederland), tepatnya di Provinsi Holland Utara dan Friesian Barat, sehingga sapi bangsa ini diberi nama Fries Holland memiliki produksi susu tertinggi dibandingkan bangsabangsa sapi perah lainnya (Webster, 1993). Berdasarkan laporan dari Direktorat Jenderal Peternakan (2014), pro- 
duksi susu di Indonesia pada tahun 2010 - 2013 hanya sebesar 798.38 ton per tahun, sedangkan konsumsi susu masyarakat Indonesia terus meningkat dari 1.013.715 ton pada tahun 2010 menjadi 1.470.237 ton pada tahun 2014 atau terus mengalami peningkatan selama kurun waktu 5 tahun dan diprediksikan akan terus meningkat pada tahun-tahun selanjutnya. Dalam rangka pemenuhan kebutuhan akan susu, pemerintah melakukan import susu sebanyak $247.495 .230 \mathrm{~kg}$ pada tahun 2011 dan $365.186 .257 \mathrm{~kg}$ pada tahun 2014 (BPS Indonesia, 2015) dari beberapa negara pengekspor susu yaitu Selandia Baru, Australia dan Perancis karena kemampuan produksi susu dalam negeri masih rendah. Rendahnya produksi susu sapi perah di Indonesia disebabkan faktor lingkungan seperti faktor iklim yang memegang peranan penting terhadap proses fisiologis dalam tubuh ternak, sehingga pada gilirannya akan mempengaruhi kapasitas produksi susu. Oleh karena itu perlu perhatian yang lebih baik untuk meningkatkan kemampuan produksi susu sapi perah tersebut. Menurut Sudono (1984) faktor iklim ini masih dapat diatasi dan tidak banyak berpengaruh apabila sapi perah tersebut diberi pakan yang berkualitas tinggi sehingga dapat berproduksi sesuai dengan kemampuannya.

Berdasarkan uraian di atas untuk pemenuhan konsumsi susu masyarakat, pemerintah harus memperhatikan peningkatan kualitas dan kuantitas melalui penyediaan bibit ternak yang memiliki mutu genetik yang baik, perbaikan pakan dan manajemen pemeliharaan. Penyediaan bibit unggul dapat dilakukan melalui seleksi. Seleksi adalah suatu tindakan dalam memilih ternak yang dianggap mempunyai mutu genetik yang baik untuk dikembangkan lebih lanjut, serta memilih ternak yang dianggap kurang baik untuk dising- kirkan dan tidak dikembangkan lebih lanjut. Agar proses seleksi dapat berjalan dengan baik maka ada beberapa sifat yang dapat dijadikan bahan pertimbangan seleksi sapi perah, diantaranya adalah melihat sifat produksi susu serta sifat-sifat lainnya seperti masa laktasi, genetik, waktu pemerahan, tata laksana pemerahan, umur dan ukuran tubuh yang berhubungan dengan produksi susu, persentase kadar lemak pada laktasi pertama, sehingga diperlukan sejumlah ternak yang mempunyai catatan lengkap. Parameter genetik itu terdiri atas nilai heritabilitas, ripitabilitas dan korelasi genetik yang dapat diketahui dengan melakukan pendugaan. Untuk menduga parameter genetik tersebut diperlukan catatan produksi susu yang ideal selama berlangsungnya periode laktasi (Hardjosubroto, 1994). Produksi susu sangat bermanfaat dan efektif pada sapi perah untuk menentukan pilihan atau seleksi, dengan demikian target penting seleksi pada sapi perah utamanya menghasilkan induk dengan produksi susu tinggi dan efisien (Anggraeni, 2012). Terdapat korelasi genetik yang tinggi antara produksi susu laktasi pertama dengan produksi susu berikutnya, hal ini berarti bahwa apabila seleksi dilakukan pada produksi susu laktasi pertama akan berhasil dengan baik terhadap produksi susu berikutnya (Suherman, 2007). Pendugaan korelasi genetik dan fenotipik pada sapi perah dapat digunakan untuk memperkirakan perubahan-perubahan pada generasi berikutnya sebagai kriteria seleksi. Seleksi untuk satu sifat tertentu akan mempunyai pengaruh yang menguntungkan atau tidak menguntungkan terhadap sifat lainnya (Warwick et al., 1990). Berdasarkan pemikiran tersebut maka penelitian ini dilakukan untuk menduga parameter genetik produksi susu dan kadar lemak sapi perah Fries Holland pada laktasi pertama 
di Balai Besar Pembibitan Ternak Unggul Baturaden.

\section{Masalah}

Peningkatan produksi susu sapi perah Fries Holland dapat dilakukan dengan cara seleksi untuk mendapatkan keturunan yang unggul dan produksi susu yang tinggi pada laktasi pertama. Informasi produksi susu perlaktasi diperoleh paling akurat dengan pencatatan setiap hari, tetapi dengan berbagai pertimbangan biasanya waktu dan biaya, maka saat ini umumnya pencatatan produksi susu adalah pencatatan secara periodik selama laktasi (Indrijani, 2008).

Menurut Hardjosubroto (1994) metode yang paling tepat dan efisien untuk mengestimasi potensi genetik sapi perah adalah menghitung nilai parameter genetik dengan kadar lemak susu yang berguna untuk mengetahui berapa banyak keunggulan atau kejelekan yang muncul dalam satu catatan yang akan muncul kembali pada catatan berikutnya. Sejauh ini parameter genetik dengan kadar lemak sangat akurat untuk mengestimasi rataan produksi susu, dapat dilihat dari hasil penelitian Setiadin (1998), di Balai Besar Pembibitan Ternak Unggul dan Hijauan Pakan Ternak (BBPTU-HPT) Sapi perah di Baturraden diperoleh hasil taksiran heritabilitas produksi susu sebesar $0,4856 \pm 0,37877$ dan hasil penelitian dari Sarnoto (2001), sebesar 0,4232 \pm 0,2456 . Taksiran nilai heritabilitas ini masuk dalam kategori tinggi, hal ini menunjukan bahwa produksi susu sapi perah di BBPTU-HPT keunggulan tetuanya dapat diwariskan kepada keturunannya (Hardjosubroto, 1994)

Oleh sebab itu perlu dilakukan penelitian yang membutuhkan catatan produksi susu selama laktasi pertama dan laktasi kedua serta persentase kadar lemak pada susu sapi perah yang dipelihara di BBPTU - HPT Sapi Perah Baturraden.

\section{MATERI DAN METODE}

\section{Tempat dan Waktu Penelitian}

Penelitian dilakukan pada

bulan November sampai dengan bulan Desember tahun 2015 di Balai Besar Pembibitan Ternak Unggul - Hijauan Pakan Ternak (BBPTU-HPT) Baturraden, Kabupaten Banyumas.

\section{Metode dan Materi}

Metode yang digunakan dalam penelitian ini menggunakan metode deskriptif dengan teknik studi kasus. Materi yang digunakan adalah data sekunder catatan produksi susu harian, catatan kadar lemak susu pada laktasi pertama dan laktasi kedua dari sapi FH selama 5 tahun terakhir terhitung sejak tahun 2009-2013. Catatan produksi susu berjumlah 17.622 pada laktasi pertama, dan 9.960 pada laktasi kedua dari 107 ekor sapi betina.

\section{Prosedur Penelitian}

Data yang dikumpulkan adalah semua data dalam bentuk softcopy dan hardcopy yang diperoleh langsung pada Pusat Data atau Sub Bagian Informasi BBPTU - HPT Baturraden, kemudian data dikelompokkan berdasarkan data pejantan, induk dan anak.

\section{Variabel Pengamatan}

Variabel yang diamati dalam penelitian ini adalah catatan produksi susu (liter) dan kadar lemak susu (persen) pada laktasi pertama dan laktasi kedua.

\section{Analisis Data}

Analisis data dilakukan pertama kali dengan melakukan standarisasi data dalam faktor koreksi lama 
laktasi 305 hari dan umur dewasa induk, data selanjutnya digunakan untuk analisis parameter genetik dari produksi susu dan kadar lemak. Parameter genetik yang dianalisis adalah heritabilitas, ripitabilitas, korelasi genetik produksi susu dan kadar lemak (Hardjosubroto, 1994).

\section{Heritabilitas Produksi Susu Laktasi Pertama dan Laktasi Kedua}

Pendugaan nilai heritabilitas dihitung berdasarkan metode korelasi saudara tiri (paternal halfsib correlation) (Kurnianto, 2009). Data analisis menggunakan metode pola satu arah (One - way Layout) dengan unbalanced design, yaitu Ulangan dengan jumlah anak perpejantan yang tidak sama (Becker, 1975). Model statistik yang digunakan sebagai berikut :

Keterangan :

$$
\mathrm{Y}_{\mathrm{ik}}=\mu+\alpha_{\mathrm{i}}+\varepsilon_{\mathrm{ik}}
$$

$Y_{i k}$ : Nilai produksi susu individu (anak) ke-k dari pejantan ke-i

$\mu \quad$ : Rataan produksi susu populasi

$\alpha \mathrm{i}$ : Pengaruh pejantan ke-i

cik : Deviasi karena pengaruh lingkungan yang tidak terkontrol pada individu (anak)

Estimasi heritabilitas dihitung berdasarkan rumus:

Keterangan :

$$
h^{2}=\frac{4^{2} s}{\sigma^{2} s+\sigma^{2} w}
$$

$\mathrm{h}^{2} \quad$ : Nilai heritabilitas

$\sigma^{2} s:$ Komponen ragam antar pejantan

$\sigma^{2} \mathrm{~W}$ : Komponen ragam anak dalam pejantan
Bila jumlah anak (k) tidak sama, maka nilai $\mathrm{k}$ dapat dihitung dengan rumus:

$$
k=\frac{1}{s-1}\left(n-\frac{\sum n_{i^{2}}}{n}\right)
$$

$$
\begin{array}{ll}
\mathrm{dB} & : \text { Derajat Bebas } \\
\mathrm{JK} & : \text { Jumlah Kuadrat } \\
\sigma^{2} \mathrm{~s} & : \text { Ragam pejantan } \\
& : \frac{K T_{s-} K T_{w}}{k} \\
\sigma^{2} \mathrm{w} & : \text { Ragam Individu (KTw) } \\
\mathrm{KTs} & : \text { Kuadrat Tengah Pejantan } \\
\mathrm{KTw} & : \text { Kuadrat Tengah Individu } \\
\mathrm{t} & : \text { Korelasi dalam kelas } \\
& :=\sigma^{2} s / \sigma^{2} w+\sigma^{2} s \\
\text { S.E } & : \text { Standart Error }
\end{array}
$$

Perhitungan standart error (salah baku) dalam estimasi heritabilitas dihitung dengan rumus (Becker, 1975):

$$
S . E\left(h^{2}\right)=\sqrt[4]{\frac{2(n-1)(1-t)^{2}(1+(k-1) t)^{2}}{k^{2}(n-s)(s-1)}}
$$

\section{Ripitabilitas Produksi Susu Laktasi Pertama dan Laktasi Kedua}

Pendugaan nilai ripitabilitas produksi susu metode pendugaannya menggunakan analisis ragam sebagai korelasi dalam kelas (Intraclass correlation), Model statistiknya menurut Kurnianto (2009). sebagai berikut :

$$
r=\frac{\sum x y-\left[\left\{\left(\sum x\right)\left(\sum y\right)\right\} / n\right]}{\sqrt{\left[\sum x^{2}-\left\{\left(\sum x\right)^{2} / n\right\}\right]\left[\sum y^{2}-\left\{\left(\frac{\left.\sum y\right)^{2}}{n}\right\}\right]\right.}}
$$

Keterangan :

$\mathrm{X} \quad$ : Sifat I (data laktasi pertama)

Y : Sifat II (data laktasi kedua)

n : Jumlah Individu

Tabel 4. Analisis Sidik Ragam Heritabilitas

\begin{tabular}{lcccc}
\hline \multicolumn{1}{c}{ Sumber Keragaman } & $\mathrm{db}$ & $\mathrm{JK}$ & $\mathrm{KT}$ & Komponen Variansi \\
\hline Pejantan (s) & $\mathrm{S}-1$ & $\mathrm{JKs}$ & $\mathrm{KTs}$ & $\sigma^{2} \mathrm{w}+\mathrm{k}_{1} \sigma^{2} \mathrm{~s}$ \\
Keturunan Dalam Pejantan (w) & $\mathrm{n}-\mathrm{S}$ & $\mathrm{JKw}$ & $\mathrm{KTw}$ & $\sigma^{2} \mathrm{w}$ \\
Total & $\mathrm{n}-1$ & $\mathrm{JK}_{\mathrm{T}}$ & & \\
\hline
\end{tabular}

Keterangan : S : Jumlah Pejantan, $\mathrm{n}:$ Jumlah Individu total, $\mathrm{k}:$ Jumlah Anak Perpejantan 
CASSOWARY - Volume 1 (2):81 - 88

ISSN : 2614-8900

E-ISSN : 2622-6545

CProgram Pascasarjana Universitas Papua, https://pasca.unipa.ac.id/

Standart error (salah baku) dalam estimasi ripitabilitas dihitung dengan rumus (Becker, 1975):

S.E $(r)=\sqrt[4]{\frac{2(m-1)(1-r)^{2}(1+(k-1) r)^{2}}{k^{2}(m-n)(n-1)}}$

\section{Korelasi Genetik Produksi Susu dan Kadar Lemak Susu}

Metode statistik yang digunakan untuk mengestimasi korelasi genetik dengan perhitungan ini menggunakan satu analisis korelasi product moment person (Wijayanto. 2008), di hitung dengan formula sebagai berikut:

$$
\mathbf{r}=\frac{\mathbf{n} \sum \mathrm{xy}-\sum \mathrm{x} \sum \mathrm{y}}{\sqrt{\left[\mathbf{n}\left(\sum \mathbf{x}^{2}\right)-\left(\sum \mathrm{x}\right)^{2}\right]\left[\mathbf{n}\left(\sum \mathrm{y}^{2}\right)-\left(\sum \mathrm{y}\right)^{2}\right]}}
$$

Keterangan :

$\mathrm{n}$ : Jumlah anak perpejantan

$\mathrm{X}$ : Variabel Pertama (Produksi Susu)

Y : Variabel Kedua (Kadar Lemak Susu)

Menurut Sugiyoto (2007) pedoman untuk memberikan kategori koefisien korelasi seperti disajikan padatabel berikut.

Tabel 5. Kategori Koefisien Korelasi

\begin{tabular}{lc}
\hline \multicolumn{1}{c}{$r$} & Kategori \\
\hline $0,00-0,199$ & Sangat rendah \\
$0,2-0,399$ & Rendah \\
$0,40-0,599$ & Sedang \\
$0,60-0,799$ & Kuat \\
$0,80-1,000$ & Sangat Kuat \\
\hline
\end{tabular}

\section{HASIL DAN PEMBAHASAN}

\section{Heritabilitas Produksi susu dan Kadar Lemak}

Heritabilitas Produksi Susu Harian

Nilai heritabilitas produksi susu pagi, sore dan produksi total produksi susu pada Laktasi pertama dan Laktasi kedua disajikan pada Tabel 9.

Nilai heritabilitas yang diperoleh ini dikategorikan tinggi. Hasil penelitian ini lebih tinggi dibandingkan hasil penelitian Rubi (2014) yang pada laktasi pertama dan kedua nilai heritabilitasnya pada pagi, sore dan totalan hanya berkisar 0,33 sampai dengan 0,44 yang hanya di kategorikan sedang. Beberapa penelitian yang dilakukan di BBPTU HPT Baturraden dan penelitian ini hasilnya sama dengan penelitian dari Wahyuni (2012) yang nilainya 0,40 \pm 0,36 dan Komala (2015) bernilai 0,4 di tempat yang sama, seperti hasil penelitian dari Yustisi (2012) dengan nilai heritabilitas $0,35 \pm 0,04$ lebih rendah walaupun semuanya dikategorikan sedang. Periode Laktasi pertama dan 2, nilai heritabilitasnya sama karena masih berkisar antara $0,20-0,40$ kategori sedang. Hardjosubroto (1994) hal ini menunjukkan bahwa kemampuan pejantan untuk untuk menurunkan sifat produksi dari tetua ke anaknya sedang, Kecermatan nilai heritabilitas ini dapat dikarenakan berbagai faktor seperti keterbatasan waktu pengambilan sampel, keterbatasan sampel dan metode yang digunakan dalam pengambilan sampel.

Tabel 9. Nilai Heritabilitas Produksi Susu Pagi, Sore dan Total Laktasi Pertama dan Kedua Di BBPTU - HPT Baturraden

\begin{tabular}{cccc}
\hline Periode Laktasi & Pagi & Sore & Total \\
\hline 1 & $0,402 \pm 0,259$ & $0,401 \pm 0,258$ & $0,402 \pm 0,259$ \\
\hline 2 & $0,53 \pm 0,299$ & $0,48 \pm 0,300$ & $0,54 \pm 0,301$ \\
\hline
\end{tabular}


CASSOWARY - Volume 1 (2):81 - 88

ISSN : 2614-8900

E-ISSN : 2622-6545

(CProgram Pascasarjana Universitas Papua, https://pasca.unipa.ac.id/

Bourdon, (1997) dalam Wahyuni, (2012) mengemukakan pendugaan nilai heritabilitas ini diharapkan dapat mewariskan sifat produksi susu pada keturunannya dengan kemajuan genetik yang tinggi.

\section{Heritabilitas Kadar Lemak}

Nilai Heritabilitas Kadar lemak susu sapi FH di BBPTU - HPT Baturraden ini dihitung dengan menggunakan korelasi saudara tiri sebapak (paternal halfsib correlation) dari 8 ekor pejantan. Kecermatan perhitungan nilai heritabilitas akan lebih baik jika paling sedikit terdapat lima ekor pejantan (Dalton 1981 dalam Wahyuni, 2012). Nilai heritabilitas yang diperoleh adalah $0,63 \pm 0,39$ dan nilai ini dikategorikan tinggi. Hasil perhitungan ini sesuai dengan pernyataan Hardjosubroto (1994) bahwa nilai heritabilitas kadar lemak susu sapi perah berkisar antara 0,30-0,60.

\section{Ripitabilitas Produksi susu dan Kadar Lemak \\ Ripitabilitas Produksi Susu harian}

Hasil pengamatan menunjukkan bahwa rataan nilai ripitabilitas pagi, sore dan total di BBPTU - HPT Baturraden termasuk kategori nilai tinggi adapun nilainya berturut - turut sebesar $(0,507 \pm$ $0,323,0,501 \pm 0,324,0,49 \pm 0,325)$. Hasil penelitian ini lebih tinggi dari hasil penelitian Novienara dkk. (2015) bahwa nilai ripitabilitas, yaitu pagi adalah 0,38 , malam 0,39 dan total 0,40 dan semuanya termasuk kategori Tinggi. Penelitian yang dilakukan oleh Saraswati (2014) nilai ripitabilitasnya pagi berkisar antara $0,33 \pm 0,00041$ sampai dengan $0,43 \pm$ 0,0056 , sore hari berkisar antara $0,33 \pm$ 0,00041 sampai $0,44 \pm 0,0055$ dan produksi total (total) berkisar antara 0,34 $\pm 0,0041$ sampai $0,46 \pm 0,0739$ nilai nilai tersebut termasuk dalam kategori sedang. Peningkatan nilai ripitabilitas diduga disebabkan oleh tingginya keragaman genetik dan keragaman lingkungan permanen sehingga menutupi keragaman lingkungan temporer (Aditya dkk, 2015). Dari beberapa hasil penelitian di BBPTU - HPT Baturadden terlihat bahwa nilai ripitabilitas sapi $\mathrm{FH}$ disana termasuk dalam kategori tinggi sampai sedang. Tingginya nilai ripitabilitas menunjukkan kemampuan sapi FH untuk dapat mengulangi sifat produksi susu pada periode berikutnya akan tinggi, begitupun sebaliknya.

\section{Ripitabilitas Kadar Lemak}

Nilai Ripitabilitas kadar lemak susu sapi pada penelitian ini adalah 0,93 $\pm 0,13$ Berdasarkan data tersebut, dapat diketahui bahwa dugaan nilai ripitabilitas BBPTU - HPT Baturraden termasuk ke dalam kategori Tinggi. Sesuai dengan pernyataan Noor (2010), bahwa dugaan nilai ripitabilitas terbagi ke dalam tiga kategori, yaitu : 0,0-0,2 (rendah); 0,2-0,4 (sedang); dan > 0,4 (tinggi). Nilai ripitabilitas yang tinggi menunjukkan bahwa kemampuan ternak untuk dapat mengulangi sifat kadar lemak susu pada periode Laktasi selanjutnya juga akan tinggi dan sebaliknya.

\section{Korelasi Genetik Produksi Susu dan Kadar Lemak}

Korelasi adalah suatu besaran nilai yang menunjukkan tingkat keeratan antara dua variable. Dari hasil analisis data di BBPTU - HPT Baturraden diperoleh korelasi genetik sebesar 2,91 \pm 0,83 . Nilai ini lebih besar dari kisaran nilai korelasi genetik antara produksi susu dan kadar lemak yang dilaporkan oleh Kurnianto (2009) sebesar 0,55.

Hasil penelitian Suherman (2007) mendapatkan nilai korelasi genetik laktasi pertama dengan daya produksi susu sebesar 0,89 . Hal ini berarti produksi susu laktasi pertama pada keturunannya secara genetik 
menentukan terhadap daya produksi susu sebesar $89 \%$ genetik dan $11 \%$ ditentukan di luar faktor genetik. Hal ini dikategorikan tinggi karena lebih besar dari 0,50. Dengan demikian individu sapi perah ini untuk produksi susu tinggi akan selalu dipertahankan sampai mencapai usia tua. Nilai korelasi genetik antara produksi susu dengan produksi lemak susu sapi FH di BBPTU - HPT Baturraden ini menunjukkan bahwa seleksi untuk peningkatan produksi susu akan diikuti dengan peningkatan produksi lemak susu.

\section{KESIMPULAN}

Berdasarkan hasil penelitian di BBPTU - HPT Baturraden, dapat diambil kesimpulan sebagai berikut:

1. Nilai heritabilitas produksi susu tahunan pada laktasi pertama kategorikan sedang dan laktasi kedua di pagi, sore dan total di dikategorikan tinggi sedang dan nilai ripitabilitas produksi susu tahunan dikategorikan tinggi.

2. Nilai heritabilitas produksi susu harian pada laktasi pertama dan laktasi kedua di pagi, sore dan total di dikategorikan tinggi dan nilai ripitabilitas produksi susu tahunan dikategorikan tinggi.

3. Rataan nilai heritabilitas kadar lemak diperoleh nilai $0,63 \pm 0,39$ yang dikategorikan tinggi sedangkan nilai ripitabilitas kadar lemaknya adalah $0,93 \pm 0,13$

Hasil perhitungan korelasi genetik produksi susu dan kadar lemak susu diperoleh nilai produksi susu untuk kadar lemak sebesar 2,91 $\pm 0,83$ sehingga nilai korelasi ini menunjukkan bahwa seleksi untuk peningkatan produksi susu akan diikuti dengan peningkatan kadar lemak.

\section{DAFTAR PUSTAKA}

Ana, E M. 1988. Produksi Susu Laktasi 1 dan Laktasi 2 dari Dua Generasi Sapi Perah Friesian Holstein. Tesis. Program Pasca Sarjana Universitas Jenderal Soedirman, Purwokerto.

Anggraeni A. 1995. Faktor-faktor Koreksi Hari Laktasi Dan Umur Untuk Produksi Susu Sapi Perah Fries Holland. Tesis. Program Pasca Sarjana Institut Pertanian Bogor, Bogor.

Anggraeni A. 2012. Perbaikan Genetik Sifat Produksi Susu dan Kualitas Susu Sapi Perah Friesian Holstein melalui Seleksi. Wartazoa 1 (22) : $1-11$.

Basya S. 1983. Berbagai Faktor yang mempengaruhi kadar lemak produksi susu sapi perah. Balai Penelitian Ternak Bogor. Wartazoa 1 (2) : 13-15.

Becker W A. 1975. Manual of Quantitative Genetics. Second Ed. Washington State University. Washington

Dewan Standarisasi Nasional 2011. SNI 3141.1 Metode Pengujian Susu Segar. Badan Standarisasi Nasional. Jakarta

Dirjen Peternakan. 2014. Buku Statistik Peternakan Departemen Pertanian, Jakarta

Dirjen Peternakan. 2015. Buku Statistik Peternakan dan Kesehatan Hewan Direktorat Jenderal Peternakan dan Kesehatan Hewan Kementrian Pertanian, Jakarta.

Fitriyani Y. 2008. Performa Produksi Susu dan Reproduksi Sapi Friesian - Holstein di BPPT - SP Cikole Lembang. Skripsi. Program Studi Teknologi Produksi Ternak. Fakultas Peternakan, Institut Pertanian Bogor, Bogor.

Firmansyah F. 2010. Performa Produksi dan Kualitas Susu Sapi FH pada 
Laktasi, Waktu Pemerahan dan Genotipe Kappa Kasein (KKasein) Berbeda di Lembang Bandung. Skripsi. Institut Pertanian Bogor, Bogor.

Hardjosubroto W. 1994. Aplikasi Pemuliaan Ternak di Lapangan. PT. Gramedia Widyasarana Indonesia, Jakarta

Hardjosubroto W dan Astuti. J.M. 1993. Buku Pintar Peternakan. Jakarta: PT. Gramedi Widyasarana Indonesia, Jakarta

Indrijani H. 2008 Penggunaan catatan produksi susu test day (hari uji) untuk menduga nilai pemuliaan produksi susu sapi perah. Disertasi. Program Pasca Sarjana. Universitas Padjajaran, Bandung.

Kurnianto E. 2009. Ilmu Pemuliaan Ternak. Edisi Pertama. Graha Ilmu, Yogyakarta.

Kurnianto E. 2010. Ilmu Pemuliaan Ternak. Lembaga Pengembangan Dan Penjaminan Mutu Pendidikan Universitas Diponegoro, Semarang

Lestari T.D. 2006. Laktasi pada sapi perah sebagai lanjutan proses reproduksi. Fakultas peternakan. Universitas Padjadjaran.

Mardalena 2018. Pengaruh Waktu Pemerahan dan Tingkat Laktasi Terhadap Kualitas Susu Sapi Perah Peranakan Fries Holstein. Jurnal Ilmiah Peternakan 3 : 107111.

Sarnoto 2001. Penaksiran Heritabilitas dan Ripitabilitas Produksi susu sapi perah FH dengan analisis variansi menggunakan jumlah catatan produksi yang berbeda di BPT - HMT Baturraden. Skripsi. Universitas Jenderal Soedirman, Purwokerto.

Setiadin J. 1998. Taksiran Heritabilitas $\left(\mathrm{h}^{2}\right)$ dan Ripitabilitas $(\mathrm{t})$ produksi susu sapi perah FH dengan analisis Variansi menggunakan tiga catatan produksi. Skripsi. Universitas Jenderal Soedirman, Purwokerto.

Sudono A, Rosdiana RF dan Setiawan BS. 2003. Beternak Sapi Perah Secara Intensif. Jakarta (ID): Agromedia Pustaka.

Suherman D. 2007. Korelasi genetik dan fenotipik produksi susu laktasi pertama dengan daya produksi susu sapi fries holland. Sains Peternakan Indonesia 2 (1) : 27 31.

Sutriyono, E. 1993. Seleksi Individu Induk Sapi Perah FH Berdasarkan Catatan Produksi Susu Sebagaian Pada Laktasi Pertama Di BPT dan HMT Baturraden. Skripsi. Universitas Jenderal Soedirman, Purwokerto.

Warwick E J, Astuti J.M dan Hardjosubroto W.1990. Pemuliaan Ternak. Gadjah Mada University Press, Yogyakarta.

Webster J.1993. Understanding The Dairy Cow. $2^{\text {nd }}$ ed. Blackwell Scientific Publication. Oxford. 